This is the refereed author version of:

Goodall, Kay E., Incitement to Religious Hatred: All Talk and No Substance?.

Modern Law Review, Vol. 70, No. 1, pp. 89-113, January 2007. DOI:

10.1111/j.1468-2230.2006.00627.x

Available from: http://hdl.handle.net/1893/262

The final publisher version is available from:

http://dx.doi.org/10.1111/j.1468-2230.2006.00627.x 


\section{Incitement to Religious Hatred: all talk and no substance?}

The Racial and Religious Hatred Act 2006 has a frenetic history. It is the culmination of six attempts in Parliament in the last twelve years to make incitement to religious hatred unlawful. ${ }^{1}$ Each attempt has met with intense criticism. But now that the legislation is here, what may it achieve?

\section{The background to the legislation}

The first version of the Racial and Religious Hatred Bill ${ }^{2}$ aimed to revise the entire existing offence of incitement to racial hatred, adding hatred of others on the grounds of their religious beliefs. ${ }^{3}$ Many thought this too wide. Lord Lester complained that the provisions were 'using a steamroller to crack a nut', ${ }^{4}$ Geoffrey Robertson QC described them as 'unnecessary and clumsily framed, ${ }^{5}$ and the Telegraph declared: 'now you face jail for being nasty to Satanists'. ${ }^{6}$

It was indeed wide. Incitement was to be by words, behaviour, or material which were 'threatening, abusive or insulting'. Intention to stir up religious hatred was not necessary. The offence would be committed if the words, behaviour or material were likely to be seen or heard by any person in whom they were likely to stir up such hatred. ${ }^{7}$

During the debate, the Lords narrowed the offence in several ways, of which three in particular - the 'Lester' amendments - are significant. First, the Lords introduced a saving for freedom of expression, discussed later. Second, they removed the 'likely to' test, so the offence could be committed only if it could be shown that the person had intended to stir up hatred. Third, they altered the mode of incitement from abuse, insult or threat to simply threat.

In the Commons at third reading, the government tried to replace the 'likely to' element with a new test of subjective recklessness. They were spectacularly defeated and the Lester amendments stayed..$^{8}$ The media reported a mood of relief: ${ }^{9}$ creating an offence of incitement

\footnotetext{
* Thanks to Francis Bennion, Adam Tomkins, Colin Gavaghan, Anna Burnside and ATH Smith for their helpful comments. The opinions expressed here, and of course any mistakes, are mine alone.

${ }^{1}$ Lord Lester proposed two amendments to the Criminal Justice and Public Order Bill, June 1994 and the (Lord) Bishop of Oxford moved an amendment in July 1994. Lord Avebury introduced a Religious Offences Bill in 2001. The government has tried three times: in the Anti-Terrorism, Crime and Security Bill in 2001; in the Serious Organised Crime and Police Bill, introduced in November 2004 and (successfully) in the Racial and Religious Hatred Bill, introduced June 2005.

${ }_{2}^{2}$ Bill 11, 54/1; introduced 9 June 2005.

${ }^{3}$ It also proposed minor changes in the wording of the existing offence: I will not discuss those here.

${ }^{4}$ Anthony Lester in Lisa Appignanensi (ed.) Free Expression is No Offence (London: Penguin, 2005) 234. See also the highly critical comments later made by FAR Bennion in 'Gilding the Lily on Religious Hatred' (2005) 14(1) The Commonwealth Lawyer 35.

${ }^{5}$ Quoted in Ruth Gledhill et al. The Times February 72005.

${ }_{7}^{6}$ Headline over report by Joshua Rozenberg, Legal Editor, The Telegraph 10 June 2005.

${ }^{7}$ Schedule, paragraphs 5-11, Bill $1154 / 1$, which would have been inserted as sections 18-23 of the 1986 Act.

${ }^{8}$ HC Deb 31 January 2006 vol 442 cols $235-244$. This was only the second defeat suffered by new Labour in the House of Commons since 1997.

${ }_{9}$ David Charter The Times 1 February 2006, Michael White; Tania Branigan The Guardian 1 February 2006, Ben Russell; James Lyons; Brendan Carlin and Neil Tweedie The Telegraph 1 February 2006. Similar views were presented in the red-top press.
} 
to religious hatred was seen as unpopular and illiberal ${ }^{10}$ and many argued that the Lester amendments created a sharper, more effective piece of legislation which had less impact on freedom of expression. Were they right? This article will consider the many questions which the new Part $3 \mathrm{~A}$ raises. It will conclude that an offence confined to requiring proof of intention simply will not work.

\section{The new offence}

The Act creates a new Part 3A of the Public Order Act 1986 for England and Wales. ${ }^{11}$ Like the law on racial hatred, ${ }^{12}$ Part $3 A$ casts a wide net. It covers speech and actions. It includes displaying material, publishing it and distributing it, and sometimes even possessing it. Those who present or direct a play, or distribute, show or play a recording, or include a programme in a programme service ${ }^{13}$ may all be caught within the offence.

The prosecution must show that the words, behaviour or material were threatening, and that the person intended to stir up religious hatred. 'Religious hatred' is defined in section 29A as 'hatred against a group of persons defined by reference to religious belief or lack of religious belief'.

The offence need not be committed in public. It can take place in private. A person may commit the offence in a private dwelling by using threatening words or behaviour or displaying (with the requisite intent) any written material which is threatening, if he has any reason to believe that this might be seen or heard by people outside. Woe betide those who live in modern tenements? The offence can also be committed in an inchoate form, such as storing material with the intention of broadcasting it.

Any offence which includes written and broadcast material will extend beyond territorial borders. Part 3A will mostly not apply to Scotland, but anyone being recorded or producing material in Scotland may commit the offence if for instance their writings appear in England or their material is broadcast over the border. ${ }^{14}$

Given the many activities which may be caught by Part 3A, politically active people need to know what is now illegal. What harms did law fail to catch, and what harms will it capture now? This is a difficult question to answer.

\section{Gaps in the law}

'When the Lord Chancellor started to talk about gaps in the law, he made me think of a rather over-zealous dentist looking round the teeth of a patient to see whether any holes need stopping'. ${ }^{15}$

\footnotetext{
${ }^{10}$ Such views were expressed throughout the parliamentary debates: see Jonathan Petre The Telegraph, 31 January 2006, Leader The Guardian January 31 2006, Matthew Tempest; Polly Toynbee The Guardian January 312006 as examples of the last comments before the final Commons debate.

${ }^{11}$ Racial and Religious Hatred Act 2006 s 4.

${ }^{12}$ Which remains unchanged.

13 This will include a cable 'programme service': for a definition, see the Broadcasting Act 1990 s 201.

${ }^{14}$ Although Part $3 \mathrm{~A}$ does not extend to Scotland other than police powers, it will affect anyone whose legal activities in Scotland also take place in England and Wales, as where Scottish newspapers are circulated in England or Scottish programme material is shown in England. See HA Kerrigan QC and Neil Addison Joint Opinion of Counsel for the Christian Institute re the Impact on Scotland of the Racial and Religious Hatred Bill (2005)

http://www.christian.org.uk/scotland/religioushatred/kerrigan\&addison opinion.pdf

${ }^{15}$ Lord Peyton of Yeovil HL Deb 8 November 2005 vol 439 col 554.
} 
One of the most compelling arguments against creating an offence of incitement to religious hatred was that English law adequately addresses the mischief already, or mostly does so. ${ }^{16}$ Many felt that the problem was lack of enforcement, not lack of legislation. Some critics accused the government of playing to Muslim voters disenchanted by UK involvement in Iraq, rather than addressing a genuine problem. ${ }^{17}$ Others complained that the gap was so narrow that filling it caused more problems than it solved.

There has been immense confusion over this point. There is certainly a powerful body of criminal law which can tackle behaviour displaying religious prejudice. From religiously aggravated abuse and violence to criminal harassment; from the Ecclesiastical Court Jurisdiction Act 1860 to the Malicious Communications Act 1988; from incitement to crime to aggravated breach of the peace,$^{18}$ most incidents would have been covered by existing law; usually public order offences.

There is ample law to cover anyone who has targeted person or property, or committed a breach of the peace. If the offender is motivated by or displays racial or religious hostility, this may also attract an enhanced sentence. ${ }^{19}$ The typical case involves words or behaviour directed against individuals, but the law can also capture actions with more generic targets. In Norwood v DPP, a man displayed a British National Party (BNP) poster beside a photograph of one of the twin towers in flames and a crescent and star surrounded by a prohibition sign. ${ }^{20}$ This display did not target any specific person, but Norwood was convicted of a religiously aggravated offence under section $5(1)(b)$ of the Public Order Act $1986 .{ }^{21}$ There is also the common law of incitement. If one incites another to commit a criminal act, this too is an offence. If a preacher exhorts his flock to 'go forth and slay the unbelievers', he may be prosecuted.

Yet supporters of the Bill often gave a very different impression. Members of Parliament offered examples of supposed gaps in the criminal law which they maintained the new offence would fill. On several occasions the examples were (no doubt unintentionally) misleading. Members listed incidents where Muslim women, including White converts, were spat at; where a White Muslim woman was verbally abused when she was observed wearing a hijab on a bus and where unnamed people incited others to fire-bomb Muslim homes. As

\footnotetext{
${ }^{16}$ Baroness Kennedy HL Deb 11 October 2005 vol 437 col 247; Lord Lester of Herne Hill 11 October 2005 vol 437 col 175.

${ }_{17}$ Lord Lester of Herne Hill HL Deb 25 October 2005 vol 438 col 1075; Ian Paisley, Boris Johnson and John Baron HC Deb 21 June 2005 vol 435 cols 718-745.

${ }^{18}$ While breach of the peace is not classified as a criminal offence in English law (although it can be a constituent of an offence), it has been classified as such for the purposes of Articles 5 and 6 of the European Convention on Human Rights (see Steelv UK (1999) 28 EHRR 603, 637 ) and it is a crime within Scots law.

${ }^{19}$ The relevant provisions are ss 28-32 of the Crime and Disorder Act 1998, as amended by s 39 of the Anti-Terrorism, Crime and Security Act 2001, which add sentence enhancement to nine existing offences; and s 145 of the Criminal Justice Act 2003, which applies to all other offences.

In Scotland, sentence enhancement for racial aggravation is governed by s 96 of the Crime and Disorder Act 1998, while religious aggravation is covered by $s 74$ of the Criminal Justice (Scotland) Act 2003. The test for the equivalent offences is 'malice and ill-will' (see below). In Northern Ireland, statutory sentence enhancement for inter alia racial and religious aggravation was introduced by paragraph 2 of the Criminal Justice (No.2) (Northern Ireland) Order 2004.

${ }^{20}$ Norwood v DPP [2003] EWHC 1564 (Admin); 2003 WL 21491815 (QBD (Admin Ct)).

${ }^{21} \mathrm{~S} 5(1)$ (b) provides that a person is guilty of an offence if he inter alia 'displays any writing, sign or other visible representation which is threatening, abusive or insulting, within the hearing or sight of a person likely to be caused harassment, alarm or distress thereby' and intends (see s 6(4)) that it be threatening, abusive or insulting, or is aware that it might be. Norwood was convicted of the offence as religiously aggravated under s 28(1)(b) of the Crime and Disorder Act 1998.
} 
Evan Harris MP pointed out during debate, all these could have been caught already. ${ }^{22}$ As baffled MPs discovered, the real gap was hard to spot. Government spokespersons were intractable when pressed to give examples: ${ }^{23}$ one of the few helpful statements is to be found in Lord Falconer's speech at second reading in the Lords. ${ }^{24}$

For practical purposes,$^{25}$ the sole area in which law was lacking is where a person incites another, not to crime, but to religious hatred. It is not unlawful to feel hatred, so incitement to hatred is not in itself an offence. Incitement to racial hatred is unlawful because it has been made so within the Public Order Act 1986. ${ }^{26}$ People were free to incite other forms of hatred. This is the crux. This brought about the many attempts to legislate. It was only when someone incited another to hate others, or acted in a way which was likely to stir up that hatred without going so far as to incite them to commit any offence - that the gap appeared. If the hatred thus stirred up was deemed 'racial', an offence had been committed. If the hatred stirred up was deemed 'religious', the incitement was lawful.

This gap is tiny. There were only 76 prosecutions for racial hatred between 1987 and 2005. ${ }^{27}$ In most cases it matters little whether hatred expresses itself as religious or racist because it will can be caught under another heading of law. The gap lies almost entirely in naming acts as religious hatred, rather than in prohibiting them.

If not for the unfortunate way in which the jurisprudence has been interpreted, this might be little more than a sophist's distinction. But precedent has determined that certain faiths are 'mono-ethnic'. It is thus easier for the prosecution to establish that an attack on Jews or Sikhs is to be deemed 'racial'. Judaism and Sikhism have been defined as mono-ethnic faiths in British law. $^{28}$

Demographic research in fact supports this. Most Sikhs in Britain share Indian ancestry, ${ }^{29}$ and Jewish identity is mostly passed on through lineage rather than by conversion. While Jewish ancestry is more diverse than Sikh, the sense of Jewish identity is strong. Even among younger British Jews, recent research found that 'almost all participants... felt themselves to be members of an ethnocultural group. ${ }^{30}$

\footnotetext{
${ }^{22}$ Sadiq Khan, Emily Thornberry, Evan Harris HC Deb 21 June 2005 vol 435 col 721-737. Dr Harris cited the three examples above. For relevant law, see for instance the Crime and Disorder Act 1998, ss 28(1)(a) and (2), as amended, and the common law offence of incitement.

${ }_{23}$ See in particular the debates in HC Deb 21 June 2005 vol 435 cols 668-762.

24 Lord Falconer of Thoroton, HL Deb 11 October 2005 vol 437 cols 162 and 169. He explained that ' $[\mathrm{t}] \mathrm{he}$ problem ....is where you are addressing people other than the people whom you are insulting or abusing with a view to stirring up hatred among them against a particular religious group' and gave several examples, such as a Muslim cleric preaching righteous hatred of Christians to a Muslim audience. (It was not clear however why some of the examples were not covered by existing law.)

${ }^{25}$ The 2003 Report of the Select Committee on Religious Offences discussed some other miniscule gaps: there is an interesting summary in chapter 3 Religious Offences in England and Wales vol $1 \mathrm{HL}$ 95-I (2003).

${ }^{26}$ Part 3; ss 17-23.

${ }^{27} \mathrm{HL}$ Deb 11 October 2005 vol $437 \mathrm{col} 274$.

${ }^{28}$ Mandla v. Dowell Lee [1983] 2 AC 548 (HL), 565. Jews and Sikhs were specifically identified in Mandla as groups defined by ethnic origins. This was a civil definition based on the definition in s.3 of the Race Relations Act 1976, but criminal law has adopted this definition: s.28 of the Crime and Disorder Act 1998 replicates s.3 except that it also includes 'citizenship' and clarifies that it is irrelevant for the offence that the victim is also a member of a religious group.

${ }^{29}$ In the 2001 Census, 91 per cent of British Sikhs were recorded as 'Indian' (and 97 per cent of Jews were recorded as 'White'): National Statistics, Focus on Ethnicity and Identity, ONS $2005,6$.

30 J Sinclair and D Milner 'On being Jewish' (2005) 20(1) Journal of Adolescent Research 91, 112. British Jews themselves tend to see Jewishness as an ethnic rather than solely a
} 
In contrast, Islam and Christianity are worldwide religions. ${ }^{31}$ So, incitement to hate Jews, Sikhs (or Gypsy travellers ${ }^{32}$ ) can fall within the racial hatred provisions, while incitement to hate Muslims or Christians ${ }^{33}$ it seems cannot. We will return to the inconsistencies in that reasoning later. What is important for now is that it is here where the anomaly lies. It is this distinction which has upset many.

Thus although the existing law covered almost all of the potential cases, the problem was not the breadth of the gap but its significance. A brief visit to the British National Party website provides an apposite example. The site is regularly purged of statements which may attract legal action. There is guidance for contributors from party leader Nick Griffin: '[a]ny connection between sex, particularly sex crime, and members of ethnic 'minorities' is dynamite'. He adds:

'Emotive words, however justified they may be, must be avoided. Truth hurts, so words like 'alien', 'vermin', 'gang' instead of 'group', and such like must be avoided. A white rapist may be described as a 'beast' or an 'animal', but a black one must merely be a 'criminal'.,34

With this in mind, it is not difficult to decode the following statement, from an article called 'The Islamic Menace':

'The hidden epidemic of molestation, abductions and rape of scores of white girls in northern English cities, all show the inherent tendency that the teachings of the paedophile Mohammed have had on some of his followers. ${ }^{35}$

It is likely that the statement is not simply anti-Muslim but racist, and will be read so by BNP supporters. Yet the BNP's legal advisers seem to believe it is not unlawful (surprisingly so, considering the reference to 'white' girls). This statement is nothing more than an incitement to hatred, so the racial/religious distinction becomes crucial. We see this in a later comment by Griffin:

'We can sometimes get away with criticising Zionists, but any criticism of Jews is likely to be legal and political suicide.'

It is because far right activists have so successfully exploited the distinction between 'racial' and 'religious' that Muslims in particular have demanded the new offence. There are other reasons: where wider common law already covers the field, a new nominate offence can make it easier to monitor prevalence, label the offender and identify a criminal history if the person re-offends. But it is the distinction between Muslims and adherents of other faiths

religious identity: Stephen Miller, Marlena Schmool and Antony Lerman Social and Political Attitudes of British Jews (London: Institute for Jewish Policy Research, 1996) ch.7.

${ }^{31}$ In fact, as DT Goldberg has pointed out, '[t]here are larger numbers of Muslim people today who are members of European or European-derivative societies than vice versa.' 'Racial Europeanization' (2006) 29(2) Ethnic and Racial Studies 331, 360.

${ }^{32}$ CRE v Dutton [1989] QB 783 (CA), 801 and 806. Note that this only applied to a subset: those of Romany origin.

The Race Relations (Northern Ireland) Order 1997 specifically defines Irish travellers as a racial group (see also A Racial Equality Strategy for Northern Ireland 2005-2010, OFMDFM, $\mathrm{NI})$.

${ }^{33}$ There is little authority for this point as regards Muslims. In the only reported case on Muslims as a 'racial group', the civil case of Walker v Hussain [1996] ICR 291 (EAT), 'Muslims' in the abstract were taken to be a religious, not a racial group, but the arguments are not explored in the appeal judgment. Sebastian Poulter cites an unreported decision of an industrial tribunal which goes into more detail: see Poulter 'Muslim Headscarves in School: Contrasting Legal Approaches in England and France' (1997) 17(1) Oxford Journal of Legal Studies 43, 62-65.

${ }^{34} \mathrm{http}: / /$ www.bnp.org.uk/articles/race act.htm, accessed 8 February 2006.

35 http://www.bnp.org.uk/articles/islamic menace.htm, accessed 8 February 2006. 
which allowed far-right activists to revile minority ethnic Muslims while other religious groups were better protected by law. It is because the far right so viciously exploit this anomaly that so many campaigned so hard to introduce the new offence.

If the anomaly had been trivial, and if the offence had already been clearly labelled by the criminal law, then new legislation might have been unnecessary. It would have done little other than demonstrate that governments believe that electorates have short memories, and that it is easier to make new law than to remind them of what exists already. But the anomaly was real, and serious.

\section{The meaning of religious hatred}

The legal source of this anomaly, however, is elusive. It is widely thought that Jews are always covered by the racial hatred provisions, while Muslims are not. This is wrong. The relevant case law has sometimes been misunderstood by commentators, and we lack interpretative guidance from cases taken to appeal. As ATH Smith has observed, in public order cases the higher courts have been loath to give it. ${ }^{36}$

The confusion appears to come from the belief that this was the conclusion reached in $R v$ $D P P$, ex $p$. Merton $L B C$. $^{37}$ Critics claim that Crown refused to bring a case against a BNP activist solely on the grounds that the literature he produced was anti-Muslim and hence antireligious, not racist. ${ }^{38}$ It is true that this was the Crown's initial decision, but they later changed it, stating that the position of Muslims is uncertain and that this did not prevent prosecution. In fact, Merton was simply a refusal to grant leave to apply for judicial review. The Council wanted a declaration that Muslims were a racial group under section 17 of the Public Order Act 1986, separate from any criminal proceedings, but Tucker $\mathrm{J}$ correctly ruled that a court could not be asked to decide a hypothetical question.

There is a genuine legal distinction, but it is a matter of degree and circumstance. If antiJudaic literature is deemed to have a solely religious target, Jews would be left unprotected. Indeed Lester and Bindman argued in 1972 that the provisions on incitement to racial hatred 'left members of the Jewish community without legal protection against religious as distinct from racial persecution'. ${ }^{39}$

In practice, though, the presumption is that a reference to Jewishness in hate literature is racist. ${ }^{40}$ It has not been difficult to prove. In $R \vee$ Edwards, ${ }^{41}$ for instance, a cartoonist drew a racially stereotypical image of a Jew draining human blood. The key events which first demonstrated the need for legislation - Caunt, Leese and fascist activities from the 30s onwards - were characterised by open anti-Semitism or express links with Nazism. ${ }^{42}$

\footnotetext{
${ }_{37}^{36}$ ATH Smith The Offences Against Public Order (London: Sweet \& Maxwell, 1987$) 43$.

${ }^{37} R \vee D P P$, ex $p$ Council of London Borough of Merton [1998] EWHC Admin 1009; $\mathrm{CO} / 3019 / 98$ (27 October 1998). A report is available at www.bailii.org

${ }^{38}$ See eg KS Dobe \& SS Chhokar 'Muslims, ethnicity and the law' (2000) 4 International Journal of Discrimination and the Law 369, 373. (This excepted, this is an excellent article). The error may have come from a misreading of an article by Peter Jepson 'Tackling religious terminology that stirs up racial hatred' (1999) NLJ 554, 556 where he briefly refers to the case.

39 Anthony Lester and Geoffrey Bindman Race and Law (Harmondsworth: Penguin, 1972) 363. See also Bob Hepple (1966) 29 MLR 306, 308.

40 This was recognised in Mandla v. Dowell Lee [1983] 2 AC 548 (HL), 561, where Lord Fraser of Tullybelton said obiter: 'it is inconceivable that Parliament would have legislated against racial discrimination intending that the protection should not apply either to Christians or (above all) to Jews'.

${ }^{41} R$ v Edwards (1983) 5 Cr App R (S) 145, 147.

${ }^{42}$ Caunt spoke openly of his anti-Semitism and Leese's supporters collected him from prison waving swastikas. See Anthony Lester and Geoffrey Bindman Race and Law (Harmondsworth: Penguin, 1972) 343-352.
} 
In contrast it will often be impossible to show the link between Islamophobic material and racist intent. It is however open to a prosecutor to show an established history of racist activity against British Muslims. Proving this link is complex because anti-Muslim hostility is more than simply anti-'Asian' hostility. ${ }^{43}$ Indeed, British-Asian Muslims themselves have a strong religious identity. Research suggests that religion is often central to how these groups differentiate themselves, particularly among the first generation. ${ }^{44}$ Muslim identity is not simply ethnic identity.

But there has been a successful prosecution in Scotland of a BNP activist who produced antiMuslim hate literature. In 2002, BNP activist David Wilson was convicted of distributing leaflets containing false accusations about Muslims in Glasgow's Pollokshields. ${ }^{45}$ The leaflets claimed that 'Muslim racists' were 'running amok' and attacking 'white' residents. Evidence was given to the court that the ethnic origin of most Muslims in Pollokshields was South Asian. The sheriff concluded that the terms Muslim and Pakistani were used interchangeably in that community. Wilson was convicted under section 19(1)(a) of the 1986 Act for stirring up racial hatred. He appealed, and the decision of the sheriff was affirmed. ${ }^{46}$

The two types of hatred are often entangled to their roots. Even in the flagrantly racist case of Edwards, the Jewish man was depicted in what was claimed (falsely) to be a religious practice - eating human blood at the festival of Purim. The problem is not bad law: it is simply that there is a blurred line and a need for proof - and perhaps also a stronger will is needed somewhere in the criminal justice process.

\section{Fair comment on Islam - or racial hatred?}

Extreme racism denigrates people and represents them as inferior: they endure a lower social or economic status and become targets of hatred or contempt. It is irrational, imputing characteristics to a whole group. It is also xenophobic, because the group is identified by supposed ethnic origin.

With this in mind, consider Norwood, which associated Islam with terrorist bombing. Islam is a mainstream world religion, not a warrior cult. It cannot therefore be a legitimate criticism of Islam to imply that most or all Muslims actively abet terrorism. There is also abundant evidence that most British Muslims practise a moderate form of Islam, so it cannot be a legitimate criticism of British Muslims to associate them with terrorism.

What is true of British Muslims is that few have a long British ancestry. Ethnically, they are 'other'. Only 4 per cent of British Muslims were classified as 'White British' in the 2001

\footnotetext{
${ }^{43}$ For evidence suggesting anti-Muslim discrimination in employment, separate from ethnic identity in the UK, see J Lindley 'Race or religion? The impact of religion on the employment and earnings of Britain's ethnic communities' (2002) 28(3) Journal of Ethnic and Migration Studies 427.

${ }^{44}$ Peter Aspinall 'Should a question on "religion" be asked in the 2001 British census' (2000) 34(5) Social Policy and Administration 584, 588-591.

${ }^{45}$ PF v Wilson Sh.Ct. 24 October 2002, unpublished (my thanks to the Crown Office for providing a copy of Sheriff Ruxton's decision). This was the first Scottish prosecution for a racial hatred offence under the 1986 Act.

See also the civil case of Walker v Hussain, cited above at FN 32. In this case the workplace was held to have two distinct racial groups: a European one and one originating from the Indian sub-continent, nearly all of whom were Muslim. It was held that discrimination on grounds of Muslim holidays was indirect racial discrimination. In Scotland, it was held in Empower Scotland v Khan [2005] UKEAT 0012, 2005 WL 2608279 (EAT) $2^{\text {nd }}$ September 2005, that in a workplace where 90 per cent of Pakistanis were Muslims, an insult aimed at Muslims could be read together with the statement that 'You Pakistanis are all the same' and amount to race discrimination.

Across the UK, 92 per cent of Pakistanis and Bangladeshis are Muslim: National Statistics, Focus on Ethnicity and Identity ONS (2005) 6.

${ }^{46}$ Wilson v PF [2005] HCJAC97, 2005 SCCR 686.
} 
Census, and nearly three-quarters had South Asian origins. ${ }^{47}$ Also, British Islam is typically seen by white British people as being Asian, because it is the South Asian (usually Pakistani) Muslims who represent Islamic interests in British political debate. ${ }^{48}$

The bigotry displayed in Norwood has the hallmarks of racism. Race or religion might define exactly who falls into the hated category, but we have already seen reports of Hindus and Sikhs subjected to anti-Muslim abuse. Because most British Muslims do not have White British ancestry, it will sometimes be possible to prove that 'Muslim' has been used as a racist marker - perhaps where the defendant has a history of racist activism. Mark Norwood, for instance, was a regional organiser for the BNP.

Because Islam is a mainstream religion, it will also sometimes be possible to distinguish between (a) angry criticisms of Islamic practices and (b) anti-Muslim abuse which is motivated by racist bigotry. It is lawful to express angry criticism of a specific extremist Muslim organisation, or to mount a hate-filled attack on characteristics which most British Muslims do have (for instance, a belief that women should cover their hair), or to denounce Islamic states which enforce harsh Hadd offences under Sharia law. These are all quite different from the sweeping anti-Muslim hatred which depicts British Muslims as members of a warrior cult or (as in Griffin and Collett ${ }^{49}$ ) a rapist sect.

Griffin and Collett defamed a group of people, most of whom are South Asian in origin and almost all of whom are not 'White British'. Had they offered fair comment on Islam - however intemperate - that would be different. If an Islamic sect in the UK advocates violence, both the state and individuals can legitimately respond. The state can proscribe the offending organisation. ${ }^{50}$ The activism of a Mark Norwood could focus only on that particular sect and so be a legitimate critique which could - depending on the circumstances - be expressed with great force. At present, it is nothing of the sort.

Here lies the basis for a manageable legal distinction. The term 'racial hatred' has not been definitively classified in criminal law as excluding any hatred expressed in religious terms. The words are to be given their ordinary and natural meaning, and while it is harder to prove that hatred targeted at Muslims addresses a racial group, it can be done.

\section{How might law distinguish between racial and religious?}

Both the reason Part $3 \mathrm{~A}$ was introduced, and the root of the furious opposition to it, is this separation between 'racial' and 'religious'. Many presume that 'race' is a clear and fixed quality of identity, while religion is not. There is much truth in this - and it would be invidious to talk up the uncertainty of the marginal case while resolutely ignoring the racial ascriptions of everyday experience. We are right to make law in the belief that people are singled out because of their 'race', and treated well or badly depending on the racial identity usually ascribed to them. Race, for most people, most of the time, is indeed clear and fixed. Religious affiliation, in contrast, is often less easily discerned by others and is not immutable (even if it is rare that people face an open choice in which faith to adopt). And religious affiliation has an obvious political and moral component, while someone's skin colour and

\footnotetext{
47 In the 2001 Census, 74 per cent were recorded as coming from an Asian ethnic background (39 per cent having been born in Asia), while only 11 per cent came from any White ethnic group: National Statistics, Focus on Religion ONS (2004) 5 . It is not clear whether those from Mixed backgrounds also had some Asian or White ancestry, though the proportion is in any case small.

${ }_{48}$ Pnina Werbner 'Theorising complex diasporas: purity and hybridity in the South Asian public sphere in Britain' (2004) 30(5) Journal of Ethnic and Migration Studies 895, 898.

${ }^{49}$ Griffin is reported as having taken advantage of a conviction of young Asian men for rape by saying (as part of a long tirade) 'These attacks are going to continue, because that is what the Qur'an says. The bastards that are in that gang, they are in prison so the public think it's all over. Well it's not. Because there's more of them.' The Guardian January 182006.

${ }^{50}$ By order under the Terrorism Act 2000, Part 2.
} 
facial features may give no guidance at all about a person's allegiances or beliefs. It does make sense for law to distinguish religion and ethnicity.

The need to reach decisions in particular cases does not however mean that legal personnel should strive to create definitions which can be packaged up and carried from case to case. It is not just that 'racial' classifications (in their narrowest sense) have no sound biological basis. ${ }^{51}$ Ethnic classifications too have no logical one beyond social and historical convenience. Instead they are a mishmash of skin colour, geographical ancestry, nationality and local community identity. ${ }^{52}$ Nationality is the only element which can reasonably said to be dominated by a co-ordinated set of rules, because its categories are created by law. There is no other absolute marker for distinguishing these social, not biological categories.

And even if such absolute markers existed, they would not mesh with local perceptions. Hostile racial ascriptions are highly contextual. At different times and in different places, a person may 'pass as white' or be singled out as alien. Meanwhile those who are always seen as alien may be 'one of us' or 'one of them' depending on whether their community is seen as integrated into British cultures. 'Race' may be mostly clear and fixed but racist hostility is volatile and hard to predict.

Religion, too, needs to be understood both as faith and as social category - as a way of marking out groups. In Scotland and Northern Ireland, sectarian conflict is between two groups who use religion mostly as a social category: it is not a battle of faith between devout believers. ${ }^{53}$ Yet conflict over faiths persists: the most recent report of the US Office of the Coordinator for Counterterrorism lists 37 'foreign terrorist organisations', of which at least 22 are expressly religious. ${ }^{54}$

The problem for law is that (as we saw above) British Muslims and South Asians are often seen by others as interchangeable. Islam has a significant public identity in Britain and so we cannot simply assume that anti-Muslim hostility is racist. But 'Muslim' as a term of abuse in Britain is often shorthand for other-than-white. Tarig Modood et al argue that 'there is a palpable racialization of Muslims going on in Britain ${ }^{55}$ - in other words, Muslim is often used to mean someone who looks 'Asian'.

This needs to be recognised in criminal law. Lawyers' perceptions, or prosecutorial decisions - or both - have become riddled with irrelevant and ahistorical distinctions taken from civil discrimination. Criminal actions are not so easy to subdivide.

A civil case may well consider a pattern of discrimination, while criminal prosecutions typically centre on a single incident. Yet social conventions in the UK now discourage explicit racist speech. This makes it hugely problematic to identify any single act as racist and to find evidence to justify that decision. Emo Gotsbachner has demonstrated how racism in everyday discourse is often expressed by omission and emphasis rather than by unambiguously prejudiced speech - often one can judge whether a statement is racist only in the context of

\footnotetext{
${ }^{51}$ While the relative incidence of genes varies among different human populations, they do not tend to vary in a way which indicates precisely demarcated groups. 'Race' as a means of genetic classification, without more, is rejected by the overwhelming majority of modern biologists. There is a wealth of writing on this, but for short and authoritative recent statements, see issue 5(8) of Nature Reviews Genetics (2004).

${ }^{52}$ Again, there has been a torrent of material on this topic. The best work on ethnicity comes from social scientists: two intelligent introductions are John Solomos and Les Back Racism and Society (Basingstoke: Palgrave Macmillan, 1996) and Kenan Malik The Meaning of Race (Basingstoke: Macmillan, 1996).

${ }^{53}$ See L Philip Barnes 'Was the Northern Ireland Conflict religious?' (2005) 20(1) Journal of Contemporary Religion 55, $59 \mathrm{ff}$. Barnes points out, for instance, that those most directly involved in the violence in Northern Ireland were not the most religious, and that the main churches did not sanction the violence.

${ }_{54}$ US Department of State, Country Reports on Terrorism 2004 (DSP, 2005) 92-111.

${ }^{55}$ Tariq Modood, Richard Berthoud and James Nazroo '"Race", Racism and Ethnicity' (2002) 36(2) Sociology 419, 422.
} 
the whole exchange. ${ }^{56}$ Civil law is better placed to do this and so it makes sense to distinguish the 'racial' and the 'religious' in civil discrimination law. The concept of racial intent in criminal law however rests on a particularly shaky house of cards. A 'contextual meaning' approach to incitement cases, judicially developed, is long overdue.

Successive judgments in the aggravation case law have led to more contextual interpretations. In the particular circumstances of a case, words such as 'African', ${ }^{57}$ 'bloody foreigners' ${ }^{58}$ and 'immigrant' ${ }^{59}$ have all been enough to convict for an offence racially aggravated. Most recently in $R \vee$ Rogers, the Court of Appeal held:

'Hostility demonstrated to foreigners because they are foreign can be just as objectionable as hostility based on a more limited racial characteristic. All who are black form a racial group, defined by reference to colour, within section 28(4), as do all who are white. This demonstrates the width of the concept of racial group in this context. It is no great extension of the concept to embrace within a single racial group all who are foreign. ${ }^{, 60}$

It would not be a huge leap to alter the law so that the use of referent words as a surrogate for race expressly fell within incitement to racial hatred. Lord Lester twice proposed an amendment which would have achieved this. ${ }^{61}$

If this worked, it would capture racial hatred directed at minority ethnic Muslims - the core problem which the government declared it wished to tackle. If so, then the sole gap left would be incitement to hatred directed at white Muslims. And even there, White people victimised (for instance) because of their relationships with Asian Muslims are covered by the racially and religiously aggravated offences. ${ }^{62}$ While incitement to hatred against them, couched in religious terms, could become a widespread problem, there is not enough evidence to justify introducing an ambiguous new law for this alone.

So is this the solution? Unfortunately, it may not be. The problem is that there are two phenomena we associate with 'religious hatred':

- $\quad$ incitement to hatred motivated by racism disguised as antipathy towards a religion

- $\quad$ incitement to hatred genuinely motivated by religious or anti-religious belief.

The first is what Part $3 \mathrm{~A}$ was designed to combat; the second is what it is far more likely to catch. Drawing on John Brewer's work on sectarianism, ${ }^{63}$ we can take this analysis a little further. There are three relatively common problems in the UK:

- $\quad$ religion used as a surrogate for racism (as in the opportunist change of language in far-right literature)

56 Emo Gotsbachner 'Xenophobic normality: the discriminatory impact of habitualised discourse dynamics' (2001) 12(6) Discourse and Society 12(6) 729, 731.

${ }^{57} R \vee$ White [2001] EWCA Crim 1756 at [17-19]; 1 WLR 1352: the word was said to have a 'racial connotation.'

${ }^{58}$ DPP v M [2004] [2004] EWHC Admin 1453 at [31]; 1 WLR 2758. The hostility was in the context of that case directed at a member of a group of people defined 'by reference to race'. See also Rv Rogers [2005] EWCA Crim 2863 at [20]; [2006] 1 Cr App R 14.

${ }_{59}$ Att Gen's Reference No.4 of 2004 [2005] EWCA Crim 889 at [24]; [2005] 1 WLR 2810.

${ }^{60} R$ v Rogers [2005] EWCA Crim 2863 at [20]; [2006] 1 WLR 962 at 968. The case is under appeal to the House of Lords.

${ }_{61}$ This was first proposed on 16 March 2005 for the Serious Organised Crime and Police Bill and the text can be found at

http://www.parliament.the-stationery-office.co.uk/pa/ld200405/ldbills/024/amend/ml024ire.htm.

${ }^{62}$ Crime and Disorder Act 1998, ss 28(1)(a) and (2), as amended.

63 JD Brewer 'Sectarianism and racism, and their parallels and differences' (1992) 15(3)

Ethnic and Racial Studies 352, 358. 
- $\quad$ religion acting as a social marker for other conflicts, economic or social (as in most Protestant/Catholic sectarianism in the UK) ${ }^{64}$

- religion as a source of conflict in its own right (as in the aggressive activities of extremist Muslims and Christians against other faiths).

We will see in the last section how difficult it is to design clear legislation which captures the first two problems. Until religious extremists adapt their rhetoric, it may be primarily the third group which is vulnerable to Part 3A. Such activists are just as deserving of punishment (and indeed may have links to the far right themselves) but any appearance of bias will be politically destructive.

\section{The 'ordinary meaning' of 'hatred'}

'I would like to incite people to hate bigotry, and I am worried about provisions that say that I cannot go round inciting people in that way. That incitement which, as we have heard, involves loathing and intense dislike - is integral to our tradition.' 65

The flaws I have described above are part of a deeper weakness in the law. The words of the Act are largely the language of ordinary speech, but ordinary speech does not define their legal purpose. Much of the disagreement over whether Part 3A conflicts with freedom of expression comes from a reluctance to address the distinction between legal meaning and colloquial meaning. 'Hate' used in ordinary discourse has many meanings, including justified dislike. As Tony Wright MP observed in the quote above, it includes loathing of religious bigotry. Even in this most passionate use of the term, inciting others to feel the same should not amount to religious hatred in the statutory sense.

Part 3A will have to be interpreted in the light of much other law. It will be interpreted through prior case law on racial hatred - after all, this statute has come about primarily because of that well-established principle of statutory interpretation. If incitement to racial hatred was not understood in the light of restrictive precedent on the meaning of 'racial group', this new statute would probably never have been proposed.

It may be however that the meaning of 'hatred' will be left to juries as judges fall back on the argument that the word should be given its 'ordinary meaning'. ${ }^{66}$ Back in 1987, ATH Smith gave a vivid example of the conflicting outcomes which can result from this approach. ${ }^{67}$ While there is a powerful argument that juries normally do not need to be directed on the meaning of ordinary words, ${ }^{68}$ more guidance would be helpful here.

There are however limits. The statute must be understood within all the usual guides to legislative intention. It is the constitutional duty of the judge to discern the legal meaning ${ }^{69}$ of

${ }^{64}$ L Philip Barnes 'Was the Northern Ireland Conflict religious?' (2005) 20(1) Journal of Contemporary Religion 55, 56 and ff.

${ }^{65}$ Dr Tony Wright, HC Debs 21 June 2005 vol 435 col 730.

${ }^{66}$ See Brutus v Cozens [1973] AC 854, though note that this case is often mistakenly taken as authority for the proposition, without more, that the meaning of an ordinary word is not a question of law.

${ }^{67}$ ATH Smith The Offences Against Public Order (London: Sweet \& Maxwell, 1987) 42-43, citing two cases in which leaflets were handed out to soldiers, urging them to desert. Despite the similar facts, one was held to amount to 'insulting' behaviour while the other was not. See also Geoffrey Bindman 'Incitement to racial hatred' (1982) NLJ 229, 300, on 'ordinary meaning' in Brutus v Cozens, above. Bindman argued that the uncertainty this causes had discouraged prosecutions. See also Timothy AO Endicott's critical commentary in 'Questions of law' (1998) 114 LQR 292.

${ }^{68}$ FAR Bennion Statutory Interpretation: A Code ( $4^{\text {th }}$ ed.) (London: LexisNexis Butterworths, 2002) 1016.

${ }^{69}$ In short, 'the meaning that correctly conveys the legislative intention': FAR Bennion Statutory Interpretation: A Code ( $4^{\text {th }}$ ed.) (London: LexisNexis Butterworths, 2002) 381. There 
the text - not to construe it with unfettered discretion either for the benefit of the accused or to help the state achieve a conviction.

Part $3 \mathrm{~A}$ will also be governed by human rights law. Article $10 \mathrm{ECHR}$ states that freedom of expression can be limited only when that is objectively necessary to protect, for instance, public order in a democratic society. The test of necessity has been glossed in case law and is not a matter of discretion for governments alone. States interfering with this right must demonstrate a pressing social need and give relevant and sufficient reasons for what they do. ${ }^{70}$ The court has emphasised the importance of 'pluralism, tolerance and broadmindedness'. ${ }^{71}$ Freedom of religious expression too is protected by Article 9 ECHR and that applies to atheists and critics of religions as much as believers. Any limits must be proportionate to the aim of achieving one of the public goods listed in the Convention. All this will limit the scope of Part 3A.

If I make what seems like an obvious point, it is because it has not always been fully grasped by legal commentators, who can appear to argue that the courts will do as they may with the law. Andrew Myers in the New Law Journal in June 2005 made the extraordinary claim that

'a (true) report about Hindu extremists burning a bus full of children on their way to Sunday school in India, or a BBC documentary [which] draws attention to the discrimination of women in countries that have adopted Sharia law ... [is] likely to stir up hatred of Hindus and Muslims respectively, and thus be crimes'. He added that 'If the Bill is passed, WH Smith will commit a crime every time a Bible or Koran is sold in its shops. ${ }^{72}$

This is simply wrong. This reading of the provision (even in its original draft at first reading) could not possibly be endorsed by any responsible British court. Denmark has been held in breach of the Convention for convicting a documentary-maker of aiding and abetting the dissemination of a racist statement. In a radio interview, members of a far-right racist organisation used foul racist abuse. Despite the exceptionally offensive language, the European Court of Human Rights stressed that 'freedom of expression constitutes one of the essential foundations of a democratic society. ${ }^{, 73}$

The Racial and Religious Hatred Bill's most formidable parliamentary critic, Lord Lester, stated in debate that there was not 'the slightest doubt' that reading from a sacred text of one of the main world religions could not in itself amount to an offence under the Bill, even in its original draft. ${ }^{74}$ The analogy with selling a sacred text is clear. But even without the guidance of the ECHR decision or the observations of a senior legal figure, it is wrong to suggest that a court could have correctly interpreted the law in this way. The British judiciary have a chequered record in protecting civil liberties but this does not mean that legislation can impliedly empower them to convict BBC documentarians of religious hatred for fair reporting of world events. And it surely goes without saying that no British court would have convicted booksellers for selling bibles.

may be real doubt over what the legal meaning is - even when the literal meaning seems clear - but the range of possible meanings is limited. My thanks to Francis Bennion for explaining his concept to me (private correspondence).

${ }_{71}^{70}$ Handyside v UK (A/24) (1979-80) 1 EHRR 737, 753-754.

${ }_{72}^{71}$ Handyside, ibid 754.

${ }_{73}^{72}$ Andrew Myers 'A crime to tell the truth' (2005) 155 NLJ 957.

73 Jersild v Denmark (A/298) (1995) 19 EHRR 1 at [31].

${ }^{74} \mathrm{HL}$ Deb 24 January 2006 vol $441 \mathrm{col} 1068$. This refers solely to reading aloud from one of these texts, in the absence of any other activities inciting hatred: such a reading could of course contribute to an offence if it was used as part of those activities. On the other hand, it is possible that the offence as the government originally framed it could in fact have caught someone who read solely from a sacred text, without intent to stir up hatred, in an inflamed situation. Nevertheless, as the offence now requires proof of purposive intention, it is difficult to imagine a situation where someone could be unjustly convicted in such circumstances. 
Even so, the complaints in their political shape have force. Fears of a 'chilling effect' are not just rhetoric. And it was disingenuous for government spokespersons to claim that the first draft of the Bill would be construed strictly by judges. ${ }^{75}$ As Bennion has emphasised, it is often supposed that criminal statutes are to be construed strictly. ${ }^{76}$ In fact it is not the job of the court to approach a clear statute with the presumption that the defendant is to be set free if at all possible. If a statute is clear, it is to be interpreted to achieve its purpose, and this is as true of criminal statutes as it is of civil ones. A statutory provision with penal effect is to be interpreted narrowly only if there is real doubt over what it means. So, if governments decide during the passage of a penal Bill that judges are to construe it strictly, they have two choices: they can word the Bill so that it directs the judges to do so, or they can leave the Bill so ambiguous that the judges are forced to. Unfortunately the government chose ambiguity.

While it is a central principle that a person should not be penalised except under clear law, it is not the only criterion, and it is certainly not a licence to patch up deficiencies which were pointed out to Parliament during the passage of the Bill. Armed by the interpretative rule in section 3 of the Human Rights Act 1998, a judge can indeed adopt a secondary interpretation which protects human rights, but the Joint Human Rights Committee had already stated that in its view the proposed legislation was human rights-compliant. ${ }^{77}$ It was misleading to argue that judges would repair any flaw. And the paramount concern in providing for the accurate interpretation of any piece of legislation must be to draft an adequate bill in the first place - not to add savings, make parliamentary statements and leave judges with an unnecessary duty to clarify it.

Furthermore, the presumption that new legislation is to be interpreted in the light of related law may not prove particularly helpful in interpreting Part 3A. This would limit interpretation, but not enough to relieve all reasonable fears. First, Part $3 A$ is separate from the provisions on incitement to racial hatred and the wording used is not identical. Although it is part of 'the family of all public order offences dealing with hatred against groups of people, ${ }^{78}$ there is greater scope for interpreting the statutory language differently.

Second, precedent on racial hatred states that the word 'hatred' is to be given its ordinary and natural meaning (the usual presumption unless there is doubt). There is little evidence that key people have thought about the need to distinguish the word 'hatred' from its colloquial connotations. During the passage of the Bill, Government spokespersons stated that there was no need to include a definition of the word because 'it is a word that a jury could perfectly well understand. ${ }^{79}$ In most areas of criminal legislation this is indeed acceptable practice. But while it is common for penal legislation to use terms from everyday speech, this particular area of crime policy is riddled with a loose use of language.

The term 'hate crime' is unsuitable to describe the statutorily aggravated offences in the UK, yet has become the preferred label. Perhaps because of this commentators regularly use 'hatred' as a synonym when discussing the provisions of statutes which enhance sentence

\footnotetext{
${ }^{75}$ It was suggested that this would be achieved by guidelines issued at a later date. Charles Clarke MP HC Deb 21 June 2005 vol 435 col 679; Paul Goggins MP, HC Stand Committee E 28 June 2005 vol 435 col 38; 30 June 2005, col. 98; HC Deb 11 July 2005 vol 436 col 599 and 31 January 2006 vol 442 col 192; Lord Bassam of Brighton HL Deb 11 October 2005 vol $437 \mathrm{col} 280$. Reference was also made by Lord Mackay of Clashfern to a Home Office memorandum on guidance in HL Deb 25 October 2005 vol 438 cols 1095 and 1125, but this is not now available.

${ }^{76}$ FAR Bennion Statutory Interpretation: A Code $\left(4^{\text {th }}\right.$ ed.) (London: LexisNexis Butterworths, 2002) 705-709.

${ }^{77}$ Fourth Report of Session 2004-05, Scrutiny: First Progress Report, HL 26, HC 224 para 1.129. Eighth Report of Session 2004-05, Scrutiny: Fourth Progress Report, HL Paper 60, HC 388 para 2.64. Fourteenth Report of Session 2004-05, The Convention on the Elimination of Racial Discrimination para 94. These comments referred to similar provisions in earlier Bills.

${ }^{78}$ Lord Lester HL Deb 24 January 2006 vol 441 col 1075.

${ }^{79}$ Lord Falconer of Thoroton HL Deb. 11 October 2005 vol 437 col 163-164.
} 
where an offence is aggravated. ${ }^{80}$ This is useful shorthand for a complex topic, used to make the law clearer to the passing reader, but its results are unfortunate. Offences aggravated by racial hostility can include incidents in which offensive racist language was used, whether or not the defendant intended them to have a racist impact. They are wider in scope than the concept of a 'hate' crime implies. A violent youth might use a foul racial epithet while committing an offence for other motives. He need not feel racist hatred. It may be enough that the mens rea is proven for the basic offence and that there be evidence that he abused the victim using racist language. In DPP v Pal, Simon Brown LJ stated:

'... I would wish to make it perfectly plain that I will reject also an argument put before us ... to the effect that section $28(1)(a)$ has no application to ... street arguments when insults may be thrown without thought being given to whether the same are racially abusive, which conduct is already covered by other offences'. ${ }^{81}$

Beyond that, the evidential burden is on the defendant to show that he or she did not intend those words to be racially hostile. In DPP v Green, Rafferty J said:

'Section 28(1)(a), as distinct from (b), creates a racially aggravated offence without the requirement to prove a racist motive. Disposition at the time is irrelevant. ${ }^{, 82}$

It is 'everyday racism' which such law captures, not only the pre-meditated obsessions of a few racist activists. Conviction of a crime of 'hatred', in contrast, carries connotations of premeditated activity, such as that associated with far-right racist organisations.

There are good arguments for punishing careless racial slurs. In a society where racism is rife and certain groups are repeatedly targeted to their fear and detriment, use of racial epithets during an offence can be inimical to public order and community relations, beyond any damage caused by the basic offence. The state can declare that it 'takes racism seriously' by enhancing sentence, and such laws may deter some citizens from open expressions of prejudice. ${ }^{83}$

There are serious implications, though, if the public and employers do not understand what it is that the legislation punishes. If many think that a conviction for an aggravated crime is proof of an act of 'hatred', they will attach a tag of pre-meditated bigotry to convictions for something else. If the offenders are characterised as purveyors of extreme forms of racism,

80 There are many examples in the press (see eg The Guardian 2 October 2003; The Scotsman 1 December 2004, The Herald 22 November 2004; The Herald 23 March 2005; The Herald 21 January 2006). There are also examples in parliamentary debates (HC Deb 31 January 2006 vol $442 \mathrm{col} 233$ ) and government reports (see eg the Select Committee on Religious Offences Religious Offences in England and Wales vol 1 HL 95-I (2003) para 2.12; Working Group on Hate Crime, Consultation Paper, (Scottish Executive: The Stationery Office, 2003) para. 1.5; NIO Consultation Paper Race Crime and Sectarianism Crime Legislation in Northern Ireland, 2002, 6; also in the Summary Paper, 3). The first report does state the law precisely in Appendix 5, as does the second report in its footnote. There are also several examples in academic discussions.

${ }^{81}$ DPP v Pal 2000 WL 191187 (DC) at [14]; [2000] Crim LR 756.

${ }^{82}$ DPP v Green [2004] EWHC QB 1225 at [16].

${ }^{83}$ On the other hand, in an interesting article, Paul H Robinson and John M Darley argue that criminal legislation often does not act as deterrent, and further argue that there is a responsibility to make law known when it is 'counter-intuitive', as I suggest this law is. 'Does Criminal Law Deter? A Behavioural Science Investigation' (2004) 24(2) Oxford Journal of Legal Studies 173-205.

For a thoughtful and intelligent discussion of arguments for and against such legislation in the UK, see in particular Mohammed $M$ Idriss 'Religion and the Anti-Terrorism, Crime and Security Act 2001 [2002] Crim LR 890. For an insightful discussion, which has not dated, of the broader aims of public order law, see ATH Smith The Offences Against Public Order (London: Sweet \& Maxwell, 1987) ch 1. 
the message is lost. Those convicted should be stigmatised for their express acts of abuse, not for imagined acts of hatred.

'Hatred' is a resonant word and it threatens to dominate wherever racial and religious crime are discussed. Take the conviction of Abu Hamza al-Mazri for both incitement to religious hatred and soliciting to murder (among others) in 2006..$^{84}$ In press commentary on his case, the hatred offence was given more emphasis, particularly in headlines. ${ }^{85}$ I did a small experiment by searching Technorati, a blog search engine, for the words 'Abu Hamza'. 27 of 100 posts mentioned Hamza's convictions. Of these, only 11 mentioned soliciting to murder at all, while 13 focused solely on incitement to racial hatred. ${ }^{86}$ While this survey can hardly be described as a representative sample of public perceptions, it suggests that some people will equate Hamza's case with Griffin and Collett's. If they then compare Hamza's conviction with the jury's failure to reach a verdict in Griffin and Collett, this may be politically troublesome.

These sorts of misunderstandings are particularly worrying when we consider a recent American study of attitudes towards "hate crime" legislation. The researchers found that people who opposed "hate crime" legislation were more forceful in trying to get others to share their views than were those who supported such legislation. ${ }^{87}$ If it happens that people also tend to behave this way in the UK, then this could heighten the confusion in which Part $3 \mathrm{~A}$ and its ilk are already mired. Popular discussion (in everyday life, not just in public debate) may be dominated by hostile discourses in which the opponents are more outspoken than the supporters.

What proportion of the British public have anything like an accurate understanding of hostility and hatred as terms of art in criminal law? Yet, without this, how will recruiters know why they are excluding someone from an appointment, ${ }^{88}$ or foreign immigration officers know why they are refusing a British person a right of residence abroad? How will the public be able to debate free speech cases if people misguidedly compare the outcomes of trials for different crimes? The government must address this before the calls for prosecutions under Part $3 \mathrm{~A}$ come flooding in.

\section{Compliance with Convention rights}

The most vociferous attacks on the Bill concerned freedom of expression. This is a right imbued with such totemic power in the contemporary British press that a reader might be forgiven for thinking that cities might fall and economies slide into the ocean before the British public would countenance the silencing of a single voice. The various views of British people are not of course represented in media ideologies. But a government should not underestimate the power of the speech trump card.

The problem is that the freedom of expression claim is not as straightforward as it seems. As a political argument that the legislation could create a 'chilling effect' which scares the layperson to silence, it has power. As a legal argument, however, there are two difficulties with it.

${ }^{84}$ BBC News 7 Feb 2006 http://news.bbc.co.uk/1/hi/uk/4690224.stm

${ }^{85} \mathrm{~A}$ few also emphasised it in the body of their reports: see eg Philip Johnston The Telegraph 8 February 2006; Paul Owen and agencies The Guardian 9 February 2006; Gary Younge The Guardian 4 Feb 2006; Daily Mail 12 January 2006.

${ }^{86}$ www.technorati.com , accessed 7 March 2006. Four posts were in another language which I did not translate; two were repeat posts and two were inaccessible. I counted only those posts in which people discussed Hamza's convictions in their own words.

87 Edward Dunbar and Andres Molina 'Opposition to the Legitimacy of Hate Crime Laws' (2004) 4(1) Analyses of Social Issues and Public Policy 91.

${ }^{88}$ The Solicitor General for Scotland, for instance, remarked in committee that the impact of a conviction for a religiously-aggravated offence 'on future job applications and emigration would be significant': Scottish Parliament Report, Justice 2 Committee, 10 December 2002, col 2430. The implication for a conviction for incitement to religious hatred in England is clear. 
First, the parliamentary Joint Committee on Human Rights said repeatedly that even the earlier, broader version of the Bill was unlikely to contravene Convention rights. A reconvened Committee did change its position and say of the equivalent provisions in the original version that the new offences 'could arguably have an adverse effect on free speech' in terms of Art.10 unless amended to make specific reference to advocacy of religious hatred that constitutes incitement to hostility, violence and discrimination'. ${ }^{89}$ The Committee did not expand on this but it probably meant (a) a need to prove purposive intention; (b) a wish to restrict the offences to words or behaviour which are threatening (leaving out those which are abusive or insulting); and (c) a legislative guarantee that this would not interfere with legitimate debate. But 'arguably' does not suggest that the Committee felt certain, and at best there is disagreement on this point. Given the safeguards in UK law, it is unlikely that any conviction would have breached Convention duties. Since the legislation has been narrowed down even Lord Lester, the most outspoken member of the Committee, has declared himself content. ${ }^{90}$ The more likely outcome is not an ECHR appeal, but the complete failure of the legislation to achieve any convictions for anti-Muslim hatred at all. The UK has repeatedly been criticised for not adjusting British criminal law to cover religious hatred as a surrogate for race. $^{91}$

Second, the UK may already be in breach of Convention rights. Both its approach to 'racial' hatred and the English common law of blasphemy appear incompatible with the Convention. Assumptions about the interpretation of 'racial' hatred mean prosecutions will usually only be brought where there has been incitement to hatred against the 'mono-ethnic' faith groups. Also, common law on blasphemy and blasphemous libe $\left.\right|^{92}$ protects only Christianity. Both these distinctions raise a question under Article $14 \mathrm{ECHR}$. Article 14 requires that the Convention rights be secured without discrimination on a range of named grounds, which include race and nationality. It is justifiable to discriminate only where this is done objectively for a reasonable purpose and is no more than is necessary to achieve that purpose. Both the narrow interpretation of 'racial' and the selective protection offered by blasphemy seem arbitrary in the light of racial equality. What are the reasonable purposes which justify these distinctions? Furthermore, as Part $3 \mathrm{~A}$ will not apply to Scotland, there will be a difference between the two jurisdictions. However, as Northern Ireland has long had separate provision on incitement to religious hatred which differs from British law, this may not itself found a case on discrimination.

On blasphemy, there is Article 9 ECHR. This protects freedom of thought, conscience and religion. The Commission has held in Kokkinakis v Greece that this includes the right to express religious beliefs and to proselytise, ${ }^{93}$ as part of the right of freedom of expression under Article 10. However, the decision was not unanimous and Mr Kokkinakis' manner while proselytising was 'inoffensive'. It is not clear how more robust religious rivalry would be treated. Even so, Art.5 ECHR permits punishment only when 'prescribed by law', and the law of blasphemy was described by the Law Commission over twenty years ago as unacceptably vague and broad. ${ }^{94}$ The European Court of Human Rights did hold in Wingrove v UK that the high threshold test for blasphemy set by the English courts was a safeguard against

\footnotetext{
${ }^{89} \mathrm{HC} / \mathrm{HL}$ First Report (2005-06) para 5.2.

${ }_{91}^{90} \mathrm{HL}$ Deb 24 January 2006 vol $441 \mathrm{col} 1075$.

${ }^{91}$ Concluding observations of the Committee on the Elimination of Racial Discrimination: United Kingdom of Great Britain and Northern Ireland CERD/C/63/CO/11 para 21. The European Commission against Racism and Intolerance also criticised the distinction which is made in UK law between 'racial' and 'religious' groups: Second Report on the United Kingdom, CRI (2001) 6 para 43; General Policy Recommendation N\%: National legisla tion to combat racism and racial discrimination CRI (2003) 8 para IV 18(d); and Third Report on the United Kingdom, CRI (2005) 27 para 14.

The Select Committee on Religious Offences has pointed out however that the problems are now mostly addressed by other law: Report of the Select Committee on Religious Offences Religious Offences in England and Wales (2003) HL 95-I, paras 95-98.

92 See ch 3 of the Report of the Select Committee on Religious Offences, ibid. These offences no longer exist in Scotland.

${ }_{93}$ Kokkinakis v Greece (A/260-A) (1994) 17 EHRR 397.

${ }^{94}$ Law Commission Offences Against Religion and Public Worship (1985).
} 
arbitrariness. ${ }^{95}$ The legal advice which informed Wingrove has however been criticised ${ }^{96}$ and although the matter is not settled, the balance of arguments suggests that English blasphemy law is incompatible.

The legal position is not simply that the UK has an imperfect body of law which has been criticised by international observers. It may have an enforceable obligation to change its law. It needed to act on incitement to religious hatred, and it may have to abolish the law of blasphemy. Whether Part $3 \mathrm{~A}$ is the best way to achieve the former remains to be seen.

\section{Does freedom of expression need special protection?}

In response to fears, the Lords added to the Bill a saving explicitly protecting freedom of expression, now found in section 29J:

'Nothing in this Part shall be read or given effect in a way which prohibits or restricts discussion, criticism or expressions of antipathy, dislike, ridicule, insult or abuse of particular religions or the beliefs or practices of their adherents, or of any other belief system or the beliefs or practices of its adherents, or proselytising or urging adherents of a different religion or belief system to cease practising their religion or belief system.'

This should have been unnecessary, given the emphasis on freedom of expression in prior law and given that Part $3 \mathrm{~A}$ is now worded more restrictively than the law on racial hatred because it leaves out 'abuse' and 'insult' and confines the criminal act to 'threat'. Lord Lester called the new saving 'a unique addition to the criminal code, ${ }^{, 97}$ but that is hardly a compliment. It adds a further layer to the legislation. While the presumption is that savings are liberally construed, any unforeseen omission will still raise questions which will need to be resolved in court. It is also not the purpose of a saving to narrow a provision further, as Lord Lester appeared to intend. ${ }^{98}$ This is not good drafting. And even if it did achieve what Lord Lester desired, it would give Article $10 \mathrm{ECHR}$ too high a priority over Article 9.

On the other hand, the Bill's defenders were unconvincing too. On safeguards, Home Secretary Charles Clarke protested that 'a complaint must be accepted by a police officer', 'the police must investigate and acquire evidence' and 'the case must be referred to the Crown Prosecution Service, which will assess it by applying evidential and public-interest tests'. ${ }^{99}$ All are routine requirements. More significant is that the Attorney General must give consent for prosecution, ${ }^{100}$ and usually the Director of Public Prosecutions will too. But Bennion rails against laws which remove the right of private prosecution. ${ }^{101}$

Charles Clarke listed several more 'safeguards' which resembled the normal criminal justice process, but he also noted that the case must go before a jury. This in fact is one of the problems in interpreting the legislation. Viscount Colville of Culross pointed out that juries do not give reasons, so to ensure the law is applied accurately, and to furnish an appeal, much perhaps too much - depends on what the judge said in summing up. ${ }^{102}$ Furthermore, the

\footnotetext{
95 (17419/90) (1997) 24 EHRR 1 at [61].

${ }^{96}$ Report of the Select Committee on Religious Offences Religious Offences in England and Wales (2003) HL 95-I at paras 12, 14 and 40. See also ECRI Second Report on the United Kingdom (CRI, 2001) 6 para 43, in which the blasphemy law is described as discriminatory. For a recent critique of the blasphemy laws, see FAR Bennion 'A New Reason for Blasphemy Reform' (2005) JP 169, 609, 629.

${ }^{97} \mathrm{HL}$ Deb 24 January 2006 vol 441 col 1075.

${ }^{98}$ HL Deb 25 October 2005 vol 438 cols 1076-1077. On savings, see FAR Bennion Statutory Interpretation: A Code (4 ${ }^{\text {th }}$ ed.) (London: LexisNexis Butterworths, 2002) 619.

${ }_{99}$ Paul Goggins HC Standing Committee E 30 June 2005 col 105.

${ }^{100}$ At 29L.

101 FAR Bennion 'Gilding the Lily on Religious Hatred' (2005) 14(1) The Commonwealth Lawyer 35.

${ }^{102}$ HL Deb 11 October 2005 vol 437 cols 198-199.
} 
House of Lords recently emphasized in Wang that a jury is entitled to direct a verdict of guilty where there is some evidence to support it, however perverse that verdict may seem to be. ${ }^{103}$

Clarification in courts of appeal would help, but it has been argued specifically in defence of the new law that few people have been prosecuted for incitement to racial hatred and that few prosecutions are expected under the new law, because its aim is to deter. ${ }^{104}$ Perhaps, then, the 'freedom of expression' saving is necessary in this complex area of law. Ideally, a welldrafted provision should be narrow enough that any remaining doubt would be dispelled by reference to Convention rights and precedent on racial hatred. But as lay juries must reach a verdict 'in all the circumstances', it is probably better that a saving was included.

\section{Silencing hate speech: the evolution of signifiers}

This brings us back to lay conceptions of the new law. Will the disquiet which enveloped the Bill now deaden public debate? I mentioned above that the racial hatred law has led to few prosecutions. Government spokespersons claim that it has been a deterrent ${ }^{105}$ but it is dangerous to assume that the legislation has silenced the right people. Together with the public uncertainty over the scope of Part $3 \mathrm{~A}$, this lack of prosecutions and convictions may enhance, not dispel, the chilling effect. In the context of the Anti-terrorism, Crime and Security Act 2001, Adam Tomkins says it 'is the splintering of terrorism from ordinary criminal justice that results in human rights abuses'. ${ }^{106}$ Without cases to adjudicate upon, bad law is not even judicially clarified, let alone exposed to judicial review.

Yet talk of the chilling effect within religious debate can be deceptive. This claim is most familiar in debates about terrorism, where it makes more sense. Supporters of small terrorist organisations rarely write for national newspapers. Tamil Tigers have not been testing out the limits of their rights of free speech under the Terrorism Act $2000^{107}$ in the pages of the Guardian or the Times. The limits of incitement to religious hatred, however, will quickly be tested by mainstream commentators. The BNP website will soon demonstrate the furthest reaches of the nasty but lawful. Terrorism and religious debate should not be carelessly compared.

The key problem may not be the chilling effect, but the difficulty of constructing a strong case to take to trial. We saw above that a major justification for creating Part $3 \mathrm{~A}$ is that extremist organisations specialise in pushing the limits of the law. Yet it is obvious that racist organisations will adapt to the new law just as they did to the old.

Hatred is a subset of obnoxious speech. That criminal law permits most of us to be rude and nasty most of the time is simply one aspect of our freedom to tell glaring, provably nonsensical, lies. The duty to truth is imposed only on relatively few professionals speaking within their sphere of authority. Tackling particular aspects of incitement to hatred is always going to be problematic for the criminal law, because freedom of expression permits people not just to present a biased version of the truth but also to tell dangerous lies. If the link between the lie and the harm is too indirect, no offence is committed. Incitement to racial hatred and now incitement to religious hatred are statutory exceptions to the general rule that the law permits people blatantly to mislead each other.

The trial of Nick Griffin and Mark Collett for incitement to racial hatred was hailed as proof that the existing law catches religious hatred. It is not. The case could only be brought because Griffin and Collett were secretly recorded in private and so spoke more openly than they

\footnotetext{
${ }^{103} R v$ Wang [2005] 1 WLR 661, [2005] EWCA Crim 3238.

104 Paul Goggins HC Deb 21 June 2005 vol 435 col 759.

${ }_{105}$ Paul Goggins HC Deb 21 June 2005 vol 435 col 759.

106 Adam Tomkins 'Readings of A v Secretary of State for the Home Department' [2005] Public Law 259, 265.

107 The Liberation Tigers of Tamil Eelam (the 'Tamil Tigers') are a proscribed organisation under Sch.2 of the Terrorism Act 2000: see The Terrorism Act 2000 (Proscribed Organisations) (Amendment) Order 2001 SI 1261.
} 
would in public. Their speeches contain several references to Asians and 'Whites'. Without these, there would have been insufficient evidence to prosecute. If the retrial succeeds, it will not demonstrate that anti-Muslim hatred could have been captured within the racial hatred law, as some have claimed. It will simply show that careless crypto-racists can get caught.

When only some types of incitement to hatred are made an offence, and when some types of abuse are identified as worse than others by the use of specified words and symbols, bigoted ingenuity quickly adapts. In Scotland, where sectarianism at football matches has become a regular form of ritual sparring, the law of religious aggravation has had to be made more sophisticated, and thus wider.

Section 74 of the Criminal Justice (Scotland) Act 2003 mostly copies the English provisions on religious aggravation. The Scottish legislation, however, has some additions. The English law specifies in section 28 of the Crime and Disorder Act 1998, as amended, that the aggravation is founded on 'hostility based on the victim's membership (or presumed membership) of a racial or religious group'. Membership can include association with members of that group. A 'religious group' means 'a group of persons defined by reference to religious belief or lack of religious belief'.

The Scottish equivalent provides that the aggravation is founded on 'malice and ill-will based on the victim's membership (or presumed membership) of a religious group, or of a social or cultural group with a perceived religious affiliation, ${ }^{108}$ which as in England and Wales includes association with members of that group. A religious group means:

'a group of persons defined by reference to their-

(a) religious belief or lack of religious belief;

But it also covers:

(b) membership of or adherence to a church or religious organisation;

(c) support for the culture and traditions of a church or religious organisation; or

(d) participation in activities associated with such a culture or such traditions. ${ }^{109}$

The Scots provision is broader because of the kinds of offence it aims to tackle. Scottish sectarianism is a complex subject, but sectarian hostility (or 'malice and ill will') was seen by the Scottish Parliament as associated most frequently with football rivalry. This is expressed by oblique linguistic associations and referential symbols. For an outsider, this symbolism is bewildering. Rangers fans have thrown potatoes onto the pitch to annoy the Catholic/lrishidentified Celtic fans, ${ }^{110}$ while their opponents have worn German flags as a provocative celebration of the new Pope. ${ }^{111}$ Both sides have adapted apparently harmless songs such as the traditional 'Fields of Athenry' and Tina Turner's 'Simply The Best'. Now, singing even the harmless lyrics is inflammatory.

Football fans, in close contact with both fellow supporters and their rivals, develop exquisitely arcane references which can be interpreted, accurately, as sectarian insults. The British National Party cannot draw on such close interaction between itself, its members and its targets and so has less opportunity for such sophistication. Even so, bigotry is fluid and fastchanging and new terms of abuse spread fast. Allusions are easily understood. Recently a Scottish court official was suspended after allegedly sending an email describing Irish people as 'green scum'. ${ }^{12}$ The statutory convolutions in which the Scottish Parliament wound itself to tackle sectarianism are instructive for those tackling expressions of religious hatred in England and Wales. It seems easier to gather evidence against minority religious preachers

\footnotetext{
${ }^{108} \mathrm{~s} 74(2)(\mathrm{a})$ - my emphasis added.

${ }^{109} \mathrm{~s}$ 74(7) - my emphasis added.

110 Devil's Advocate Sunday Herald August 142005.

${ }_{111}$ Alan Pattullo The Scotsman 25 April 2005.

${ }^{112}$ Douglas Fraser The Herald February 12006.
} 
than against racist far-right activists. Nick Griffin, after all, denies that he is a racist. ${ }^{113}$ Can Part $3 \mathrm{~A}$ meet the challenge?

\section{The problem of proving intention}

The final question then is: can Part 3A work? Branch after branch has been hacked off. Lord Lester insisted that the Government's original proposals suffered from 'the twin vices of vagueness and uncertainty and over-breadth and a lack of proportion'. ${ }^{114}$ The Lords then took out the 'likely to' test and limited the offence to 'threatening' words, material or behaviour. They aimed to create a statute which would do precisely the job for which it was designed, and no more.

But that 'likely to' test so criticised by the Lords was inserted in Britain's incitement to racial hatred provisions in $1976,{ }^{115}$ precisely because research had found that the need to prove purposive intention ${ }^{116}$ was so restrictive that prosecutions were likely to fail. ${ }^{117}$ So, Parliament broadened the offence. No longer was there a need to prove intent to stir up hatred: it was enough that it was 'likely to' be stirred up.

Despite this, no floodgates opened. Peter Thornton noted that there were few prosecutions under section $5 \mathrm{~A}$, and they rarely succeeded. ${ }^{118}$ In 1986 Parliament revised the law again: this time the prosecution could prove either intent or likelihood. It was still not enough. Attorneys General feared that high-profile cases would fail and were reluctant to consent to prosecutions.

One might think that a religious hatred provision would be different. But between 1970 and 1987, Northern Ireland had just such a provision on incitement to religious hatred - with a purposive intention test just like that in Part 3A. And, as Brigid Hadfield pointed out in 1984, the wording of the Northern Irish provision was 'such as to render highly unlikely a successful prosecution under it'. ${ }^{19}$ Three years later Parliament re-wrote the Northern Irish provisions to include an alternative 'likely to' test, based on the British offence. ${ }^{120}$ Yet even though the Northern Irish law encompasses actions which 'arouse fear' as well as those which stir up religious hatred, records show just one conviction so far. ${ }^{121}$

Part 3A covers a wider range of actions than the 1965 Act did (particularly actions in private dwellings) but the threshold test of intent is the same. It will be possible to infer intent, even if the person denies it. ${ }^{122}$ But the prosecution will probably have to prove the purposive intention

${ }^{113}$ BBC news report February 32006.

${ }^{114}$ HL Deb 25 October 2005 vol 438 col 1074.

115 The new provision, inserted by s 70 Race Relations Act 1976, became s 5 A of the Public Order Act 1936. It was repealed by s 40(3), Sched. 3 Public Order Act 1986.

${ }^{116}$ On purposive intention, see Richard Card (2000) Public Order Law (Bristol: Jordans, 2000) 139 and 187.

117 Home Office Racial Discrimination Cmnd 6234 (1975) at para 126. CERD praised the change: see Ineke Boerefijn and Joanna Oyediran in Sandra Coliver Striking a Balance (Essex: Article 19, 1992) 27.

118 Peter Thornton Public Order Law (London: FTPL, 1987) 61.

119 Brigid Hadfield 'Incitement to religious hatred' [1984] PL 231, 241. On the other hand, Patricia M Leopold ('Incitement to hatred - the history of a controversial criminal offence' [1977] PL 389, 401-402) rather dismissively claims that this was less a flaw of the legislation and more that 'a Northern Irish jury was unable to be objective about a case of incitement.'

${ }_{120}$ The Public Order (Northern Ireland) Order 1987, Part 3 (ss.8-17). The change followed criticisms that the earlier provisions were ineffective: see T Murphy in Sandra Coliver Striking a Balance (Essex: Article 19, 1992) 267.

${ }_{121}$ HL Deb 3 March 2005 vol 431 col 34 (WA). The data date back only to 1993, as there are no records available before that. The previous legislation only led to one (failed) prosecution between 1970 and 1992: see T Murphy in S Coliver ibid.

${ }_{122}$ See Anthony Lester and Geoffrey Bindman on intent in the 1965 Act: Race and Law (Harmondsworth: Penguin, 1972) 362. 
to stir up religious hatred. ${ }^{123}$ What is worrying that both Hadfield and Thornton mention cases where no conviction was ever achieved - not because the police did not investigate, or because the Attorney General refused to allow a prosecution, but because the test of purposive intention was too difficult to surmount. ${ }^{124}$

It will be even harder to get a conviction under Part $3 \mathrm{~A}$, because it permits abuse and insult. A person will have a defence under the freedom of expression saving if he intended 'only' to insult or express antipathy. In the example above from the BNP website, it is unlikely that the comments would amount to words which are 'threatening'. ${ }^{25}$ Also, the authors could argue that they are expressing antipathy towards the religious practices of some Muslims who find authority for their actions in the Koran, but not all Muslims. We may suspect otherwise, but as the article links passages of the Koran to the actions of 'some' followers, a jury could decide that the article was protected by section 29J. The website does elsewhere disavow both racist and anti-Muslim intent ${ }^{126}$ and this might persuade a jury not to convict. ${ }^{127}$ So if the BNP website can continue publishing such comments, what comfort can Muslims draw from the new law?

'The second clip has another woman relating how another Muslim has told her daughter "Us Pakis are going to have to watch what we're doing with you young 'uns now."

Together the clips make it crystal clear that for me to have used the phrase "Paki street thug" to describe a specific type of swaggering young scumbag equivalent, as I told the jury on Friday, to the "hoodies" and "white trash" who besmirch our own community - was not intended to be, and could not possibly be taken to be, any kind of racist slur or insult. In Keighley, as in fact all over working class Britain, the word is a simple, neutral, descriptive term, used by all communities.' 128

To back up their claim that they were not using abusive language, Griffin and Collett were allowed to show the jury video extracts of a documentary which alleges that South Asian people refer to themselves as 'Pakis'. This was supposed to demonstrate that the word is inoffensive. Bindman has pointed out that the 1965 test also allowed wily defendants to produce dubious material in the courtroom, supposedly to prove their innocent intentions. ${ }^{129}$ For incitement to racial hatred today, proof of intention is not essential, but for religious hatred it is. Prosecutors will fear bringing a case where purposive intention has to be proved, if it can become a showroom for arguments like this.

The legislative history in Britain and Northern Ireland suggests that the new Part $3 \mathrm{~A}$ will be almost unenforceable. Without a confession, it will be very difficult to prove the purposive intention. Perhaps some extremist clerics who confess their intentions may be caught, which would be no bad thing; and much more legitimate than deporting them without trial. But those at whom the legislation was supposedly aimed - racist activists - will have little trouble adapting their rhetoric. The Lords have pruned this statute so hard they have left it a stump. Minority faith leaders will see this as a betrayal.

The only way in which we can have genuinely free expression is to protect those minorities who would also like to exercise it. A society does not have freedom of expression if white

\footnotetext{
${ }^{123}$ See Richard Card Public Order Law (Bristol: Jordans, 2000) 87.

124 Brigid Hadfield 'Incitement to religious hatred' [1984] PL 231, 242; Peter Thornton Public Order Law (London: FTPL, 1987) 61.

${ }^{125}$ The word has been given its ordinary meaning: Brutus v Cozens [1973] AC 854.

${ }^{126}$ http://www.bnp.org.uk/candidates2005/manifesto/manf4.htm ('we are not 'racists") and http://www.bnp.org.uk/articles/islamic menace.htm ('we have nothing against Muslims').

${ }^{127}$ Although not always - see Patricia M Leopold's discussion of $R$ v Jordan [1967] 1 All ER 486, in 'Incitement to hatred - the history of a controversial criminal offence' [1977] PL 389, 395.

${ }_{128}$ From Nick Griffin's online blog 30 January 2006 http://freespeechontrial.blogspot.com/

${ }^{129}$ Geoffrey Bindman 'Incitement to racial hatred' (1982) NLJ 229, 300.
} 
activists can freely stir up hatred and so ensure that their minority victims become too frightened to reply.

But the result of the final amendments to Part $3 A$ is - in law at least - almost entirely a return to the status quo. Its sole effect is likely to be on public perceptions of what is unlawful. The greatest barrier to public enlightenment is likely to be pundits who will not be able to resist telling tall tales about the silencing of free speech. Parliament must accept some of the blame. Part 3A may be so misunderstood that perhaps it is just as well that it has been made useless. But international observers will not stay silent, and the UK may have to answer for its errors. 